\author{
Contents list available at Multidisciplinary Journal website \\ Multidisciplinary Journal \\ Journal homepage: https://jurnal.unej.ac.id/index.php/multijournal
}

\title{
Pengaruh Tingkat Pengetahuan dan Stres Kerja terhadap Pencegahan Kecelakaan Kerja pada Pekerja Giling dan Ketel di PG Rejo Agung Baru Madiun
}

\author{
Effect of Knowledge Level and Work Stress on Prevention of Work Accident in Milled and Kettle \\ Workers at PG Rejo Agung Baru Madiun
}

\author{
Caesar Kridha Bagus Prahartiko, ${ }^{1, *}$, FX Ady Soesetijo ${ }^{2}$, Ristya Widi Endah Yani ${ }^{3}$ \\ ${ }^{1}$ Magister Ilmu Kesehatan Masyarakat, Universitas Jember \\ ${ }^{2}$ Fakultas Kedokteran Gigi, Universitas Jember \\ ${ }^{3}$ Fakultas Kedokteran Gigi, Universitas Jember \\ Email: caesarkridhabp@gmail.com
}

\begin{abstract}
This research aims at disclosing the effect of knowledge level and work stress on prevention of work accident in Milled and Kettle Workers. It is a qualitative research employing analytic observation method using cross sectional design. The sample, including 115 workers in Milling and Kettle Section in PG Rejo Agung Baru Madiun, were selected by using total sampling. Regression Test by SPSS 22 was applied to analyze the data. Findings demonstrate the sig value of knowledge level indicating 0.889 and sig value of stress level of 0.027 . It reveals that there is no effect from workers' knowledge level, in contrast, work stress affect the prevention of work place accident. Therefore, more stimulation on knowledge level and support for workers are prominent to minimize their work stress.
\end{abstract}

Keywords: Knowledge level, sugar mill, work accident, work stress

ABSTRAK. Pekerja pabrik gula sangat rentang dengan kecelakaan kerja di tempat kerja. Tujuan dari penelitian ini adalah untuk mengetahui pengaruh tingkat pengetahuan dan stres kerja terhadap pencegahan kecelakaan kerja pada pekerja giling dan ketel. Penelitian bersifat kuantitatif dengan metode observasi analitik dengan desain cross sectional. Sampel penelitian adalah 115 pekerja dari bagian giling dan ketel di PG Rejo Agung Baru Madiun yang diambil menggunakan total sampling. Uji Regresi dengan alat bantu SPSS 22 dalam menganalisa data. Hasil yang didapatkan pada nilai sig tingkat pengetahuan adalah 0.889 dan nilai sig stres kerja sebesar 0.027 artinya tingakt pengetahuan tidak terdapat pengaruh sedangkan stres kerja terdapat pengaruh dalam pencegahan kecelakaan kerja. Sehingga perlunya stimulasi lebih terhadap tingkat pengetahuan serta dukungan lebih terhadap pekerja dalam meminimalisir stres kerja yang terjadi.

Keywords: Tingkat Pengetahuan, Pabrik Gula, Kecelakaan Kerja, Stres Kerja

\section{Pendahuluan}

Kecelakaan Akibat Kerja merupakan kejadian yang tidak diduga maupun dikehendaki oleh semua pekerja serta sering kali tidak dapat diduga yang berakibat menimbulkan kerugian baik waktu, properti atau harta benda bahkan korban jiwa di dunia kerja. Kecelakaan kerja terjadi disebabkan kontak antara sumber energi seperti mekanis, kimia, fisik dan kinetik yang berakibat dapat menimbulkan cedera pada manusia, lingkungan maupun alat kerja. ISO 14001,2004 menjelaskan kecelakaan akibat kerja dapat diartikan dengan suatu peristiwa atau yang menimpa pekerja dengan menimbulkan penyakit akibat kerja, cedera, bahkan kematian akibat kerja[1].

Pencegahan kecelakaan kerja adalah suatu tindakan pencegahan kecelakaan kerja yang ditujukan kepada mesin, lingkungan, perlatan \& perlengkapan kerja serta faktor manusia. Kondisi lingkungan diharuskan memenuhi persyaratan keselamatan yang aman, keadaan tempat kerja sesuai standar keselamatan kerja hingga perencanaan membnutuhkan perhatian lebih dalam memenuhi persyaratan selamat[2]. Kecelakaan kerja dapat dicegah dengan beberapa cara diantaranya menggunakan program Triple-E. Tripele-E adalah program untuk mencegah Kecelakaan kerja dengan isi sebagai berikut : 1) Education. Pemberian pendidikan terhadap pekerja merupakan hal yang sangat penting dalam meningkatkan pengetahuan pekerja dalam upaya pencegahan kecelakaan kerja. 2) Engineering. Teknik dilakukan pertama kali adalah melengkapi berbagai peralatan beserta memperhatikan alat kerja tentang pengoperasiannya, sehingga apabila telah selesai digunakan, dapat mematikan alat tersebut tanpa ragu. 3) Enforcement 
merupakan tindakan pelaksanaan dengan memberi jaminan bahwa aturan/SOP mengenai pengendalian kecelakaan telah dilaksanakan[3].

Pengetahuan merupakan hasil dari tahu terhadap suatu objek melalui indra yang dimiliki (mata, hidung, telinga dan lain sebagainya) atau sebuah hasil dari pengindraan manusia. Secara alami, penginderaan menghasilkan sebuah pengetahuan tersebut yang sangat dipengaruhi oleh intensitas perhatian dan persepsi pada objek yang berkaitan. Pengetahuan sebagian besar didapat melalui indera pendengaran dan indera penglihatan[4].

Pengetahuan adalah komponen-komponen mental yang dihasilkan dari seluruh proses secara lahir maupun bawaan yang didapat melalui pengalaman individu [5]. Stres kerja merupakan kondisi ketegangann yang dapat mempengaruhi proses emosi, berpikir, hingga kondisi seseorang. Stres dapat mengancam kemampuan dari individu dalam menghadapi lingkungan sekitar sehingga mengganggu seluruh pelaksanaan pekerjaannya [6]. Cooper dalam Wijono (2010) menyebutkan bahwa stres kerja dapat dipengaruhi beberapa faktor diantaranya iklim kerja, hubungan antar pekerja, tuntutan dari kantor hingga terkait pengembangan karir[7].

\section{Bahan dan Metode}

Waktu Pelaksaanaan adalah bulan Juni - Agustus 2019. Lokasi penelitian adalah PG Rejo Agung Baru Madiun pada bagian Giling dan Ketel.Penelitian menggunakan Lembar Kuesioner yang telah valid dan reliabel kepada 115 responden pekerja pada bagian giling dan ketel di PG Rejo Agung Baru Madiun.

Penelitian ini merupakan penelitian kuantitatif dengan metode observational analitik dengan observasi analitik kepada para pekerja giling dan ketel di PG Rejo Agung Baru Madiun dengan variabel Tingkat pengetahuan, stres kerja serta pencegahan kecelakaan kerja menggunakan instrumen kuesioner. Masing-masing kuesioner variabel terdiri 10 item untuk tingkat pengetahuan, 11 item untuk stres kerja dan 12 item untuk pencegahan kecelakaan kerja. analisa yang digunakana adalah regresi logistik menggunakan alat SPSS 22.0.

\section{Hasil dan Pembahasan}

\section{Analisa Univariat}

Tabel 1. Analisa Univariat Tingkat Pengetahuan

\begin{tabular}{|c|l|c|c|}
\hline Variabel & Kategori & $\mathrm{N}$ & $\%$ \\
\hline \multirow{4}{*}{ Pengetahuan } & Baik & 67 & 58 \\
\cline { 2 - 4 } & Kurang & 48 & 42 \\
\cline { 2 - 4 } & Total & 115 & 100 \\
\hline
\end{tabular}

Tabel 1 menjelaskan distribusi dari variabel tingkat pendidikan dimana kategori tingkat pendidikan baik sebanyak 67 responden (58\%) dan kategori tingkat pendidikan yang kurang adalah 48 responden (42\%). a. Stres Kerja

Tabel 2. Analisa Univariat Stres Kerja

\begin{tabular}{|l|l|l|l|}
\hline Variabel & Kategori & $\mathbf{N}$ & $\mathbf{\%}$ \\
\hline \multirow{4}{*}{ Stres Kerja } & Ringan & 65 & 57 \\
\cline { 2 - 4 } & Berat & 50 & 43 \\
\cline { 2 - 4 } & Total & 115 & 100 \\
\hline
\end{tabular}

Tabel 2 yaitu stres kerja menjelaskan kategori stres kerja responden dimana 65 responden mengalami stres kerja ringan $(57 \%)$ serta stres kerja berat dialami oleh 50 responden $(43 \%)$.

b. Pencegahan Kecelakaan Kerja

Tabel 3. Analisa Univariat Pencegahan Kecelakaan Kerja

\begin{tabular}{|l|l|l|l|}
\hline Variabel & Kategori & $\mathbf{N}$ & $\mathbf{\%}$ \\
\hline Pencegahan & Baik & 63 & 55 \\
\cline { 2 - 4 } Kecelakaan & Tidak Baik & 52 & 45 \\
\cline { 2 - 4 } Kerja & Total & 115 & 100 \\
\hline
\end{tabular}

Tabel 3 menunjukkan bahwa pencegahan kecelakaan kerja dengan kategori baik sebanyak 63 responden $(55 \%)$ dan kategori pencegahan kecelakaan kerja tidak baik sebanyak 52 responden $(45 \%)$.

\section{Analisa Bivariat}

Tabel 4. Analisa Bivariat

\begin{tabular}{|l|l|l|l|}
\hline Variabel & B & S.E & Sig \\
\hline Pengetahuan & -.057 & .410 & .889 \\
\hline Stres Kerja & .864 & .391 & .027 \\
\hline
\end{tabular}

Tabel hasil uji regresi logistik didapatkan nilai koefisien Beta pada variabel penegtahuan sebesar - 0.057 dan variabel stres kerja sebesar 0.864. Adapun nilai SE pada variabel pengetahuan didapatkan nilai 0.410 dan variabel stres kerja 0.391 dan nilai sig sebesar 0.889 untuk variabel tingkat pengetahuan serta 0.027 pada variabel stres kerja. Hasil nilai sig dari variabel tingkat pengetahuan adalah 0.889 dan nilai sig dari variabel stres kerja 0.27 . Syarat Ho adalah apabila nilai sig $>0.05$ maka ditolak dan Ho diterima apabila nilai sig $<0.05$.

Tingkat pengetahuan dari hasil penelitian yang telah dilakukan didapatkan hasil tidak terdapat hubungan dimana nilai sig tingkat pengetahuan lebih besar daripada nilai sig (0.05) yaitu 0.889 . Tingkat pengetahuan merupakan proses yang dihasilkan dari proses lahir dan bawaan yang didapat melalu pengalaman individu. Tidak adanya pengaruh tingkat pengetahuan terhadap pencegahan kecelakaan kerja dikarenakan pekerja belum sepenuhnya memahami pentingnya pengetahuan terhadap SOP (standard operational procedure) dalam bekerja, memahami ramburambu peringatan yang telah dipasang, melakukan check ulang mesin kerja baik sebelum maupun sesudah digunakan hingga pentingnya penggunaan APD (alat pelindung diri) saat bekerja dimana dapat mengurangi resiko terjadinya kecelakaan kerja.

Hasil ini tidak sejalan dengan penelitian yang dilakukan oleh Widajati dan Martiana (2017) dimana dijelaskan terdapat pengaruh tingkat pengetahuan terhadap pencegahan kecelakaan kerja. Hal ini didasari dengan 
adanya pelatihan yang diberikan. Sebuah pelatihan maupun seminar tentang keselamatan kerja dapat meningkatkan pengetahuan pekerja dalam mencegah terjadinya kecelakaan kerja di tempat kerja. Pelatihan juga dapat meningkatkan pemahaman terhadap kondisi serta resiko yang ada di tempat kerja.

Asumsi dari peneliti mengapa tingkat pengetahuan tidak terdapat pengaruh terhadap pencegahan kecelakaan kerja di PG Rejo Agung dikarenakan pengetahuan harus melewati sikap, jadi dengan adanya sikap maka sebuah tindakan dapat dilakukan. Begitu juga dengan pengetahuan, apabila pekerja rata-rata memiliki tingkat pengetahuan baik namun sikap belum baik, maka tindakan pencegahan kecelakaan kerja juga tidak akan sesuai dengan tujuan.

Adapun untuk stres kerja terdapat pengaruh terhadap pencegahan kecelakaaan kerja dengan nilai sig hitung kurang dari nilai sig (0.05) yaitu 0.027. Stres kerja dapat berpengaruh terhadap pencegahan kecelakaan kerja, hal ini karena stres kerja dapat mempengaruhi kondisi pekerja sehingga membuat tidak fokus dalam bekerja. Kondisi stres kerja menyebabkan para pekerja sulit konsentrasi sehingga tidak fokus dalam bekerja yang beresiko terjadi kecelakaan kerja. Pekerja juga berinteraksi langsung dengan mesin bergerak/mesin kerja yang dapat menimbulkan heat stres yang dapat memicu terjadinya stres kerja.

Heat stress dapat terjadi pada lingkungan kerja baik indoor maupun outboor, dimana apabila lingkungan kerja melebihi batas termal pekerja, dapat memicu terjadinya stres kerja[8]. Hasil pengaruh stres kerja terhadap pencegahan kecelakan kerja sejalan dengan penelitian yang dilakukan oleh Sunariyanto (2014) dimana variabel stres kerja berpengaruh terhadap pencegahan kecelakaan kerja pada pekerja [9].

Goldenhar et all (2003) dalam Barkhodari (2019) menjelaskan mengenai dampak dari stres kerja dapat mengurangi konsentrasi, gangguan memori, ragu terhadap apa yang akan dikerjakan sampai kesulitan dalam pengambilan sebuah keputusan [10]. Dukungan adalah salah satu bagian yang diperlukan oleh pekerja, dengan adanya dukungan para pekerja merasa dihargai serta dapat berdampak baik untuk stres kerja pekerja dalam pencegahan kecelakaan di tempat kerja.

\section{Kesimpulan}

Meskipun tingkat pengetahuan tidak berpengaruh terhadap pencegahan kecelakaan kerja, namun pihak PG Rejo Agung Baru Madiun disarankan untuk selalu memberi pelatihan agar tingkat pengetahuan terus bertambah. Sebab dengan adanya pelatihan dapat memberikan stimulus dalam merangsang tingkat pengetahuan pekerja dalam pencegahan kecelakaan kerja yang terjadi. Stres kerja pada pekerja dapat diatasi dengan selalu memberi dukungan serta memfasilitasi kebutuhan dalam bekerja contoh penyediaan APD, memberi rasa aman kepada pekerja dan lain-lain. Adanya rasa aman dapat menimbulkan perasaan tenang terhadap pekerja dalam melakukan tindakan. Sehingga stres kerja lebih termanajemen. Lingkungan kerja dapat mempengaruhi stres kerja yang menimbulkan heat stres, jadi saran kepada pihak PG Rejo Agung Baru Madiun untuk sesekali mengadakan pemeriksaan berkala/rutin terhadap para pekerjaMemuat kesimpulan yang diperoleh dan saran-saran untuk penelitian selanjutnya (jika ada).

\section{Ucapan Terimakasih}

Terima kasih kepada PG Rejo Agung Baru Madiun, Kota Madiun yang telah berkenan memberikan ijin atas pelaksanaan penelitian ini.

\section{Referensi}

[1] Prayitno, H. (2016). Keselamatan dan Kesehatan Kerja (K3) pada Standard Operasional Prosedur (SOP). Ponorogo: Forum Ilmiah Kesehatan (Forikes).

[2] Suma'mur. (2009). Hygiene Perusahaan dan kesehatan kerja (HIPERKES). Jakarta: Sagung Seto.

[3] Sedarmayanti. (2011). Tata Kerja dan Produktivitas Kerja: Suatu Tinjauan DariAspek Ergonomi Atau Kaitan Antara Manusia Dengan Lingkungan Kerjanya. Bandung: Mandar Maju.

[4] Notoatmodjo, S. (2014). Ilmu Perilaku Kesehatan. Jakarta: Rineka Cipta.

[5] Reber, S., \& Reber, S. (2010). Kamus Psikologi. Yogyakarta: Pustaka Pelajar.

[6] Handoko, T. (2008). Manajemen Personalia. Yogyakarta: BPFE Yogyakarta.

[7] Wijono. (2012). Psikologi Industri dan Organisasi. Jakarta: Kencana Prenada Media Grup.

[8] Hamerezaee, M., Dehghan, S., Golbabaei, F., Fathi, A., Barzegar, L., \& Heidarnejad, N. (2018). Assessment of Semen Quality among Workers Exposed to Heat Stress : A Cross-Sectional Study in a Steel Industry. Safety and Health at Work.

[9] Sunariyanto, K. (2014). Pengaruh Keselamatan dan Kesehatan Kerja Serta Stres Kerja Terhadap Kinerja Karyawan. Jurnal Ilmu Manajemen.

[10] Barkhoudari, A., Malmir, B., \& Malakoutikhah, M. (2019). An Analysis of Individual and Social Factors Affecting Occupational Accidents. Safety and Health at Work. 